\title{
The Role of Virtual Educational Environment in English for Specific Learning Purposes
}

\author{
Angela Andrienko \\ Department of Foreign Languages \\ Southern Federal University \\ Taganrog, Russia \\ angelaandrienko22@gmail.com
}

\begin{abstract}
The article concerns the role of the virtual educational environment as one of the valuable factors in Master students' of non-linguistic major English for Specific Purposes Course effective learning. The paper considers the results of Computer Engineering graduate students' foreign language professional communicative competence development in English for Specific Purposes learning through the use of the Internet Educational Platform. The research, conducted at Southern Federal University, Russia, was based on the carried out testing, surveys in the form of a questionnaire, interviews, and classroom observations. The importance of the formation of foreign language professional communicative competence in the process of English for Specific Purposes learning is analyzed. The impact of Edmodo Learning Management System as a part of English for Specific Purposes department-based integrated Courseware is discussed. The definitions of the terms "Virtual Educational Environment," "Learning Management System," "English for Specific Purposes," "foreign language professional communicative competence" are viewed.
\end{abstract}

Keywords-Virtual Learning Environment (VLE); Learning Management System (LMS); the Internet Educational Platform; English for Specific Purposes (ESP); professional collaboration; Master students of non-linguistic major; foreign language professional communicative competence; English as a Foreign Language (EFL); E-learning Courseware.

\section{INTRODUCTION}

Nowadays, the formation of professional communicative competence in English as a Foreign Language (EFL) is not entirely analyzed in the process of English for Specific Purposes (ESP) learning at Higher School. This issue is of a great importance, especially, for students of non-linguistic major. The international requirements of foreign language proficiency [1] are aimed at gaining a certain level of professionally oriented communicative competence. The process of the integration of Russia into the multicultural global educational and informational environment enhances the problem of the necessity of foreign language communicative competence formation for graduate university students to be able to perform professionally oriented interaction with specialists of different countries, to successfully develop the future career, to face the challenges of competitiveness in the modern world.

During a process of ESP teaching, a certain lack of using Virtual Learning Environment (VLE) as a valuable instrument in EFL competency development has been found. Thus, the Department of Foreign Languages has reported on the recent demand to look for appropriate ways to apply innovative educational multimedia tools to upgrade the department-based E-learning Course.

Investigating the educational impact of VLE is important for motivating and inspiring graduates of Computer Engineering major to improve linguistic and communicative skills, intensify teamwork, and collaboration on the professional problems, related to the students' specialty.

Also, it is high time to study and apply new approaches in Course design, grading, peer review, and teachers' feedback.

Alongside with the department multimedia means, the Edmodo Internet Education Platform was chosen among a good deal of existing Learning Management Systems (LMS) of this kind (such as Canvas, Blackboard, Google Classroom, Moodle, Bright space, Schology, Infinite Campus) [2], which are widely and successfully applied in a lot of international and Russian Universities.

The terms "Virtual Learning Environment" (VLE) and "Managed Learning Environment" (MLE) are often interchanged [3]. We share Margaret Rouse's (2011) opinion that "A Virtual Learning Environment (VLE) is a set of teaching and learning tools designed to enhance student's learning experience by including computers and the Internet in the learning process [3]."

VLE complex consists of the following main sets: curriculum sections (educational modules), student's portfolio, electronic communication means, links, a bank of Web 
publishing, etc. A good advantage of the given platform is that a teacher has extra rights to modify the context according to the adopted rules of an academic portal usage.

The Master students' ESP portfolio is viewed as an instrument to develop students' personal development in academic activities during a professionally oriented learning process. Students' ESP portfolio contains the syllabus, Courseware, grading, checking up materials, assignments, and other materials, related to foreign language communicative competence development.

We consider LMS and MLE as a part of the VLE. Among a wide set of LMS, we chose the Edmodo Internet portal [4], which implies different methods to be used in ESP virtual class, such as professionally oriented discussions, case studies, teamwork, role plays, conference participation, collaboration with international students, and project-based interaction. The project method is based on modeling the students' professionally oriented interaction in a group during the virtual class.

The Edmodo education Internet portal was founded by teachers Nic Borg and Jeff O'Hara (2008) who viewed the Edmodo's goal as "to help educators harness the power of social media to allow easy customization of a class" [5].

\section{PRoblem}

\section{Problem Statement}

At the present stage of information technology development, VLE plays an important role in forming professional communicative competence of graduate students in EFL in the process of ESP learning at the University. Students with a high level of the given competence are ready to collaborate with international specialists worldwide, discussing professionally-oriented problems, related to their major.

Learning English for Specific Purposes (ESP) is an important component of professional education for all majors at the University. The purpose of studying ESP is to develop foreign language professional communicative competence of students. The high level of the formation of this competence makes it possible to carry out professionally oriented communication in English and use ESP in the scientific sphere.

Among a lot of definitions of ESP, there is no unity in defining this term: "English for Specific Purposes" or "English for Special Purposes". Tom Hutchinson and Alan Waters (1987) in their work "English for Specific Purposes: A Learning-Centered Approach [6]" put the term "English for Specific Purposes" into practice. The scholars describe ESP as the basis for a different area of professional communication [7]. They define ESP as a means of communication in various professionally oriented spheres: in business and economics English for Business and Economics, in psychology - English for Psychology, in social sciences - English for Social Sciences, medicine - English for Medical Sciences and a number of other professional directions.
Then Duddley-Evans and St John published "Developments in English for Specific Purposes" (1998), providing a profound definition of ESP [7].

T. Hutchinson and A. Waters (1987) note the importance of the ESP learning process for the needs of the students (needs analysis) [1, p. 8].

The importance of directing the course of ESP for the needs of students is noted by R. Milrud (2013) as well. Speaking about the essential difference between the program of teaching language in "common goals" from teaching language in "special purposes," R. Milrud believes that "English for Special Purposes is actually the English language for learning" [8].

Among the Russian researchers this subject is viewed by $\mathrm{O}$. G. Polyakov [9] and S. G. Ter-Minasova [10]. Scholars emphasize not only the study of the language thesaurus, but also the importance of a communicative approach, and intercultural communication.

The future of ESP at Higher School is the intensive development of learning and progress control technologies based on the intensive use of multimedia tools, E-learning courses, textbooks, the search for effective ways of distance learning with the aim of professionally oriented communication with specialists at the international level.

Students with a high level of foreign language professional communicative competence and ESP skills development are able to participate in students' scientific conferences, share professional experience, and study continuously through their lives, gaining valuable results in their career. On the contrary, students with a poor level of the given competence and undeveloped ESP skills are unable to sustain the demands of the competitive world market, and cannot apply to the positions they would like to occupy.

At Southern Federal University ESP Course is based on the multilevel, interdisciplinary, and competency approaches.

The competency approach is aimed at the formation of a foreign professional communicative competence of future graduates. A multilevel approach is aimed at continuous EFL learning at all educational levels at the University: undergraduate level (Bachelor's Degree), graduate level (Master's Degree), postgraduate level (Doctoral Degree).

Interdisciplinary collaboration between the Department of the Foreign Languages and Technical Departments (Computer Engineering, Electronic Engineering, Radio Engineering, and Economic) of Southern Federal University gives students a possibility to find perspective ways to learn ESP on the integrated base, maintaining the professional competencies both in Russian and English languages. The result of such cooperation between the departments is the collaborative writing of manuals, the creation of electronic textbooks, educational programs, educational and methodical syllabi, and Courseware. 
Currently, the educational portal Edmodo (www.edmodo.com) is available for three categories of users: teachers, students, and their parents.

This LMS is free and completely focused on the educational community, its advantage as a social network is the lack of external advertising of entertainment content and commercialization. The registration process on the site is simple, you only need to enter your login, password, and Email, there is no need to specify phone numbers and personal information of students. The agreement on the processing of personal information allows the teacher to adjust the profile photos of students and their account if these data contradict the educational mission of the portal.

The Edmodo educational platform was chosen as an interactive LMS for studying the discipline "English for Specific Purposes" in the system of educational and methodological training of graduates of non-linguistic specialties as a means of effective communication for professional self-development between students and teachers, sharing experiences, creating presentations, and professionally oriented projects according to students' major.

You can use the video and text materials available on the site and upload your own videos, participate in quizzes, polls, share experiences, and receive a teacher's advice (a feedback can be provided by a teacher in video mode as well).

A teacher has the opportunity to make assessments in the electronic journal, monitor the academic progress of students, evaluate the activity of students with Edmodo badges, attach the schedule of studies, tests, exams, methodological materials, questionnaires, and presentations, to create a bank of materials. It is convenient to use the Edmodo library.

The portal also provides a large selection of materials for various grades and educational categories, allowing users to share materials internationally under the motto "share resources from across the world [2]."

Tasks are to be uploaded into the assignment window, opened by a teacher, who provides comments and instructions for students and indicates the deadline, so students themselves can determine their educational trajectory by scheduling the task at a convenient time for them. The teacher has the option to close the assignment window after the expiration of the task or leave the access open.

Using Edmodo educational portal has a positive value as a means of professional interaction at the international level (participation in professional communities, conferences, including conferences held in the professional environment of Edmodo: Edmodocon). Student groups created on Edmodo platform, help a teacher and students to prolong the educational process, not limiting it only to classroom time, create the prerequisites for long life education.
The Purpose of the Research consists in finding effective ways to form Master students' foreign professional communicative competence by means of Virtual Learning Environment in the process of English for Specific Purposes learning.

Research Question: "What is the impact of the Internet education portal Edmodo as a part of VLE on the formation of graduate students' foreign language communicative competence in the process of ESP learning?"

\section{Hypothesis}

Hypothesis. The level of formation of foreign language professional communicative competence of Master Students' of the Computer Science Major in ESP learning will be much higher if

- the potential of Edmodo LMS is used as an integrated part of the ESP learning complex;

- a special educational and methodical syllabi, and Courseware, related to Edmodo usage, are carried out;

- appropriate educational conditions for ESP learning in VLE are developed.

The main aim of the competency approach to ESP learning is the formation and development of foreign language professional communicative competence. This gives students the possibility to collaborate successfully with foreign specialists and to carry out scientific research on students' major. ESP learning is viewed as a part of the foreign language professional communicative competence development [11]. The above-mentioned competence gives students the ability

- to perform cross-cultural professionally oriented communication as EFL personality;

- to interact in a multicultural community with different national values, norms, and traditions;

- to create a positive, tolerant spirit in the process of cross-cultural communication;

- to choose relevant ways of verbal and nonverbal means of communication, based on the knowledge of cultural and scientific peculiarities in academic and professional environment;

- to keep national and professional self-identification in the world of international integration and mobility [11].

\section{Methodology}

In the carried out research 60 students from Computer Engineering Department of Southern Federal University, Russia, took part. The participants were aged between 22 and 26 years, of male and female gender.

Today, ESP is a necessary part of students' professionally oriented development in the process of EFL learning at the University worldwide. 
At Southern Federal University undergraduate students of non-linguistic major study English for General Purposes (EGP) course in their first and second years and start studying English for Specific Purposes (ESP) Course being in their third and second years.

Master students precede studying ESP for two years. In this connection, it is worth mentioning that some Master students of the control and experimental groups came from different Higher Schools where ESP Course has not been previously studied.

During the period of EGP learning, undergraduate students start forming and developing linguistic, sociocultural, discourse, communicative, and strategic competencies. The interdisciplinary approach allows Master students to develop their professional and information competence. Students study professional disciplines in the native language and in EFL and continue developing their professional skills in ESP class.

\section{Methodological Approaches}

Before the research the personal data about the participants, taking part in the experiment, were collected and analyzed. To have the same sample of participants in the control and experimental groups the data were collected in the form of the carried out surveys, progress testing, and questionnaire.

The following approaches were used to form foreign language professional communicative competence:

- the concept of management and informatization of educational environment (D. A. Novikov (2015), O. B. Lebedev (2006), V. I. Toktarova (2015), etc.);

- the concept of electronic and distance learning (M. G. Bondarev (2015), E. S. Polat (2011), A. A. Kalmykov (2005), V. I. Soldatkin (2003), etc.);

- the competency-based approach (A. V. Khutorskoy (2004), L. N. Khutorskaya (2004), I. A. .Zimnyaya (2009), etc.);

- the theory of informatization of education (S. A. Beshenkov (2011), Y. S.Branovsky (2015), A. P.Ershov (1985), V. M.Monakhov (2010), etc.);

- the distance educational technologies (A. A. Andreev (2002), Biggs (2003), S. L.Lobachev (2002), E. S. Polat (2011), etc.);

- the interdisciplinary approach and cross-cultural and professional interaction (A. S. Andrienko (2007), L. K. Salnaya (2009), I. A. Zhaturova (1997), etc.).

\section{Data}

The present research data were collected at the base of the carried out surveys in the form of a questionnaire, class interviews, and in the process of testing the acquired level of Master Students' foreign language communicative competence.
The study sample included 60 Master students (40 male and 20 female) of the students of the same Major (Computer Science) at Southern Federal University. The research was carried out during three academic semesters in 2015-2016 and 2016-2017 academic years. The participants were divided into two numerically equal groups (30 participants each): control and experimental ones. Both groups consisted of the equal number of Master students (23 students in each group) who previously studied ESP Course, being bachelor students at Southern Federal University and students who came from other Higher Schools and have not ever studied any ESP Course (23 students in each group).

At the beginning and at the end of the research, the Master Students were given a set of tests to examine the level of the foreign language professional communicative competence development.

The participants provided the data about their gender and age as well. The level of the formation of professional communicative competence in EFL was tested by the researcher at the base of linguistic, grammar and professionally oriented assignments, related to the criteria demands on the formation of EFL competency [1] (Table III).

\section{RESUlts}

The results in the pre-tests and post-tests between the control group and the experimental group were compared and interpreted, as well as the results between the pre-tests and the post-tests within individual groups. The questionnaire results were analyzed and interpreted as well. Finally, conclusions were made and the contribution to the methodology of foreign language learning and teaching was specified.

The gathered data showed that more than half of the respondents were male (Table I) and more than a half of graduates were over 21 years old (Table II).

\section{TABLE I. GENDER OF THE GRADUATE STUDENTS}

\begin{tabular}{|l|c|c|}
\hline \multicolumn{1}{|c|}{ Sex } & Number & \% \\
\hline Male & 40 & 66.7 \\
\hline Female & 20 & 33.3 \\
\hline
\end{tabular}

TABLE II. AGE OF THE GRADUATE STUDENTS

\begin{tabular}{|c|c|c|}
\hline Age & Number & \% \\
\hline 21 & 12 & 19.9 \\
\hline $\begin{array}{c}\text { Over 22- } \\
\text { 26 }\end{array}$ & 48 & 80.1 \\
\hline
\end{tabular}


TABLE III. THE LEVEL OF THE FORMATION OF A PROFESSIONAL COMMUNICATIVE COMPETENCE IN ESP

\begin{tabular}{|c|c|c|c|c|}
\hline $\begin{array}{l}\text { Number } \\
\text { of Master } \\
\text { Students } \\
\text { of } \\
\text { Computer } \\
\text { Science } \\
\text { Major }\end{array}$ & $\begin{array}{l}\text { Common } \\
\text { European } \\
\text { Level } \\
\text { Descripti } \\
\text { on }\end{array}$ & $\begin{array}{l}\text { Common } \\
\text { European } \\
\text { Framewor } \\
\text { k Level }\end{array}$ & $\begin{array}{l}\mathbf{I} \\
\mathbf{E} \\
\mathbf{L} \\
\mathbf{T} \\
\mathbf{S}\end{array}$ & $\begin{array}{c}\text { Southern } \\
\text { Federal } \\
\text { University } \\
\text { Grade }\end{array}$ \\
\hline 0 & $\begin{array}{l}\text { Mastery- } \\
\text { Upper } \\
\text { Advanced }\end{array}$ & $\mathrm{C} 2$ & 8 & $86-100$ \\
\hline 15 & $\begin{array}{c}\text { Effective } \\
\text { Proficienc } \\
\text { y-Lower } \\
\text { Advanced }\end{array}$ & $\mathrm{C} 1$ & 7 & $85-71$ \\
\hline 20 & $\begin{array}{l}\text { Vantage- } \\
\text { Upper } \\
\text { Intermedia } \\
\text { te }\end{array}$ & B2 & 6 & $71-84$ \\
\hline 34 & $\begin{array}{l}\text { Threshold } \\
\text {-Lower } \\
\text { Intermedia } \\
\text { te }\end{array}$ & B1 & 5 & $66-70$ \\
\hline 12 & $\begin{array}{c}\text { Waystage- } \\
\text { Elementar } \\
\mathrm{y}\end{array}$ & A2 & $\begin{array}{l}3 \\
- \\
4\end{array}$ & $60-65$ \\
\hline 5 & $\begin{array}{c}\text { Breakthro } \\
\text { ugh }\end{array}$ & $\mathrm{A} 1$ & 0 & $64-0$ \\
\hline
\end{tabular}

The research was focused on finding out the influence of VLE on the progress of students after completing the ESP Course. Before the experiment, there were not any significant differences in Master students' EFL professional communicative competence development during ESP learning (Fig.1) and in professionally oriented skills in reading, writing, vocabulary, and translation development as well (Fig. 2).

At the end of the ESP Course, there was a valuable improvement in the level of foreign language professional communicative competence development in the experimental group (Fig. 3).

It is seen that professionally oriented communicative activity plays an important role in ESP learning in both groups (Fig. 1 and Fig. 2).

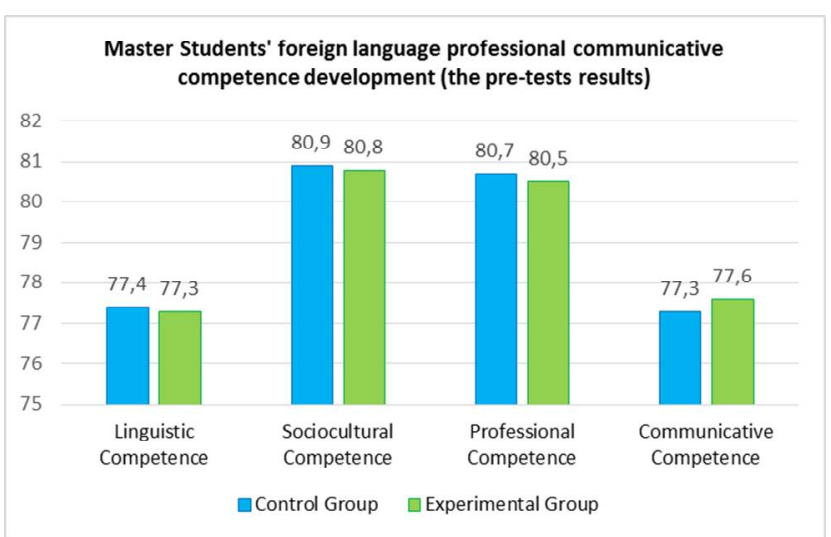

Fig. 1. Master Students' foreign language professional communicative competence development (the pre-tests results)

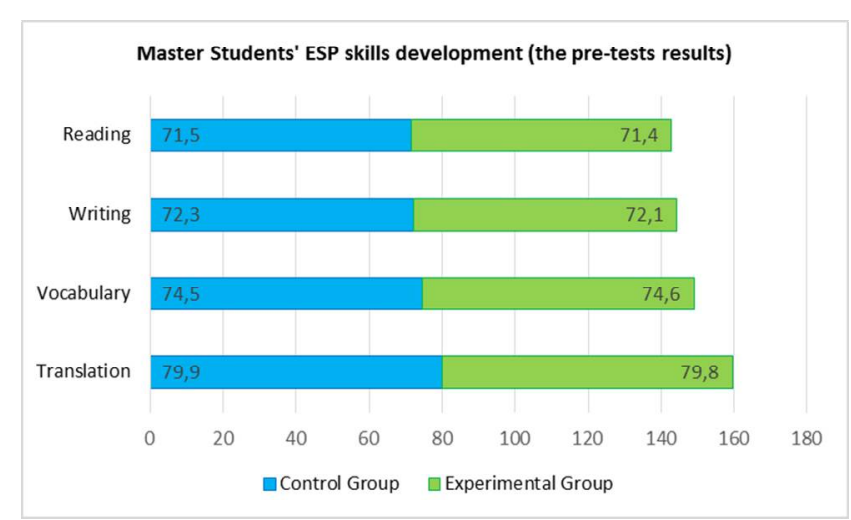

Fig. 2. Master Students' skills development (the pre-test results)

We can trace a valuable increase in the experimental group, related to professional and communicative competencies, caused by intense virtual professionally oriented collaboration and teamwork, especially during the usage of the Edmodo Internet educational platform (Fig. 3).

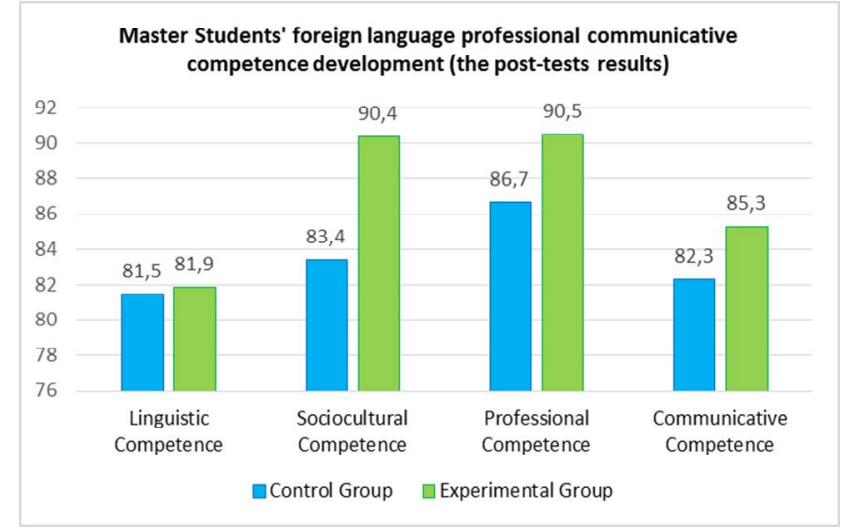

Fig. 3. Master Students' foreign language professional communicative competence development (the post-tests results)

Foreign language communicative competence of Master Students of Computer Science major in ESP learning by means of the Edmodo Internet educational portal rose significantly, especially in the sphere of the students' activities, connected with sociocultural and professional competences. The level of communicative competence rose sufficiently as well as, related to teamwork, texts-on-specialty discussion, creating presentations and projects. (Fig. 3 and 4).

We can state that in the control group with face-to-face traditional learning there are positive changes in the level of EFL professional communicative competence development during ESP learning as well, especially in graduate students' translation and vocabulary skills. (Fig. 4). 


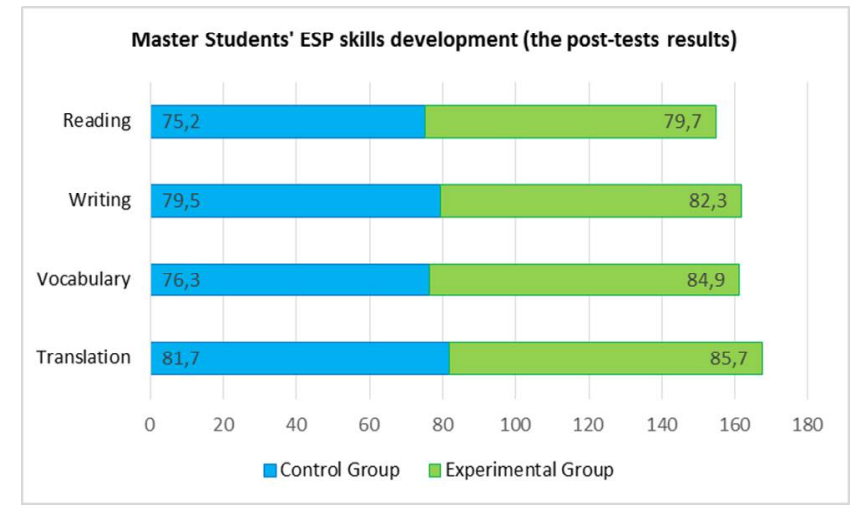

Fig. 4. Master Students' skills development (the post-test results)

The data analysis proves that communicative activities play an important role in making ESP learning a successful process and in creating an authentic professionally oriented environment.

The usage of the Edmodo Internet education portal allows students to take part in activities, connected with teamwork, abstract, paper and article writing, critical reading and texts-onspecialty discussion, creating presentations and project-based assignments.

The research proved the hypothesis that the LMS as a part of VLE can be considered a successful educational tool in ESP learning.

\section{DISCUSSION}

\section{The findings}

The carried out survey indicated that the level of the formation of foreign language professional communicative competence in the process of the organized ESP learning was increased, mainly, but not only through the use of VLE and, particularly, by means of the Edmodo Internet educational portal as LMS. The impact of the Internet educational portal as a part of VLE was measured, taking into account the influence of not only a pure VLE but blended learning as well because, during the experiment, students were eager to have meetings with a teacher at the office, group collaboration, presentations, roundtable discussions in a faceto-face class. The reason is an insufficient level of graduate students' linguistic competencies to comprehend instructions properly and to follow the feedback through the education portal. Also, some of the Master students appear to have a certain lack of information technology skills to deal with the provided assignments and electronic resources.

In this connection virtual collaborative process and group teamwork through the Edmodo Internet platform as LMS should not be viewed as pure distance one. Some Master students would like to have an opportunity to present professionally oriented assignments in class after a teacher's feedback provided virtually. But this kind of learning activity is not always possible because of the lack of academic hours at the University syllabus. Thus, a valuable advantage is that LMS gives students the possibility to work continuously.

As we are living in the global virtual environment, Internet, being an effective tool to develop students' EFL competencies, was used both by the students of the control and experimental groups in the process of ESP learning.

\section{Limitations of the research and future exploration}

During the current research, not all components of the foreign language professional competence have been tested. The investigation of the students' qualities during the communication process of ESP learning virtually and in person, as well as critical thinking abilities, and peer reviewing methods will be the issues of the further studies.

The formation of Master students' groups of nonlinguistic major at Southern Federal University is very heterogeneous from the point of view of language skills (reading, writing, listening, and speaking) and competency development (linguistic, sociocultural, discourse, strategic, social, informative, linguoprofessional, personal), on the one hand, and of the students' major (the students received different specialties in their previous studies), on the other. Thus, the control and experimental groups included some students who had linguistic majors in their undergraduate studies.

The carried out research showed the necessity to continue finding further ways to develop foreign language professional communicative competence by using Edmodo as VLE at the University.

\section{CONCLUSION}

The research showed that VLE plays a valuable role as a part of the integrated ESP Courseware at the University. Using Edmodo as LMS gives students a possibility to organize their academic activities more successfully, to collaborate with international representatives, work in groups, develop and maintain EFL competencies in the professionally oriented environment. Working with the educational portal inspires students to acquire new professional and behavioral skills and to further develop them in the future professional sphere.

The study proves the effectiveness of VLE usage in the formation of foreign language professional communicative competence. The research showed that VLE could be a considerable factor in planning ESP strategies. The Internet educational portal Edmodo has a significant impact on the process of group collaboration and a project-based students' activity in ESP learning. VLE is a valuable tool, aimed at enriching learning strategies of students, the processes of grading and students' progress, feedback, pedagogical approaches and Courseware design at the University. During virtual collaboration students are treated as critical thinking participants and constructive actors of the ESP process. 
The usage of the Internet educational platform helps to encourage the students' community to learn developmentally and creatively, to work collaboratively, finding new approaches to ESP teaching and learning, and professional interaction worldwide. The practical value of the research concerns the results of the Master students' foreign language professional communicative competence development through the use of VLE and can be used in the process of ESP learning and planning ESP Courseware at the University.

\section{REFERENCES}

[1] Introductory Guide to the Common European Framework of Reference (CEFR) for English Language Teachers. Cambridge: Cambridge University Press, 2017.Retrieved from: http://www.englishprofile.org/images/pdf/GuideToCEFR.pdf.

[2] Edmodo. Alternatives and Competitors (2017). Learning Manage Systems. G2 Crowd. Retrieved from: https://www.g2crowd.com/products/edmodo/competitors/alternatives.

[3] Rouse, M. (March, 2017)/ Virtual learning environment (VLE) or managed learning environment (MLE). TechTarget. Whatls.com. Retrieved from: http://whatis.techtarget.com/definition/virtual-learningenvironment-VLE-or-managed-learning-environment-MLE.

[4] Edmodo. (September, 2008) A global educational network. Retrieved from: https://www.edmodo.com.

[5] Sultan, N and Al-Lail H. J. (2015). Creative Learning and MOOCs. Hernessing the Technology for a 21 st Century Education. Cambridge Scholars Publishing, p. 129.

[6] Hutchinson, T., A. Waters (1987). English for Specific Purposes: A learning-centered approach. Cambridge: Cambridge University Press.

[7] Dudley-Evans, T. and St John, M. J. (2005). Developments in English for Specific Purposes: A Multidisciplinary Approach, Cambridge: CUP, 2005.

[8] Millrud, R. (2013). Language learning for specific purposes: essence, technique, reflection. Topic in the system of vocational education. Retrieved from: http://iyazyki.prosv.ru/2013/05/english-special/.

[9] Polyakov, O. G. (2003). English for Special Purposes: Theory and Practice, Moscow.

[10] Ter-Minasova, S. G. (2000). Language and intercultural communication, Moscow.

[11] Andrienko, A. S. Development of professionally oriented communicative competence in English as a second language of students at a technical university (based on the credit-module technology of education): Thesis, Rostov on Don, 2007, 282 p. 